\title{
Students' Experiences in Facebook: Adoption and Utilization at University Level
}

\author{
Sumera Irum ${ }^{1 *}$, Tarique Bhatti ${ }^{1}$, Noor Mohammad ${ }^{2}$ and Muhammad Dilshad ${ }^{3}$ \\ ${ }^{1}$ Continuing and Computer Education (DC and CE) Faculty of Education, University of Sindh, Pakistan; \\ sumera_irum@yahoo.com, bhatti_tariq2007@yahoo.com \\ ${ }^{2}$ Faculty of Education, Lasbela University, Pakistan; noorm_noor@yahoo.com \\ ${ }^{3}$ Govt. Degree College Pratabad, Hyderabad, Pakistan; dilshadhyd@gmail.com
}

\begin{abstract}
Objective: Facebook and other Social networking platforms provided opportunities for students to become technologically sufficient and efficient on one side. Methods/Findings: However, on the other side, there are some negative effects of social networking sites like wastage of precious time by students in reading Facebook posts or chatting with online friends, study distraction, avoiding homework and perpetration before the exams. The descriptive survey type research method was used to conduct the study. The students were selected from B.Ed. (Hons) Elementary Program, Faculty of Education, and University of Sindh and from Department of Education, University of Karachi. (300) students selected randomly to participate in the study. Close ended questionnaire was designed through the help of literature. The majority of respondents agreed that Facebook provides many benefits to students like to get new information, entertainment, killing leisure time, socialization, meeting new friends, surfing, and updating status etc... Application: Facebook had also negative impact of students' lifestyle, playing and physical activities, social norms and ethics, in the end, it is recommended that Facebook should be used purely for educational and communication purposes, and parents should remain aware about the Facebook account of their children.
\end{abstract}

Keywords: Adoption, Facebook, Influence, Students, Teachers, University, Utilization

\section{Introduction}

Telegraph and letters were the main communicating sources before the invention of the telephone. Communication mode was very slow and accessible to very few people. Then the invention of Internet technology revolutionized the whole communicating system, around the whole world. The pace of communication becomes faster and cheaper, in the next generation web 2.0 technologies likes, Facebook, tutors, blogs, etc. introduced and an open new vistas of swift communication. All these inventions in communication technology are now recognized as social networking and social media. In today's time which have become very powerful and popular source of communication and information.
The Facebook is very common and highly used social networking site. According to different survey's highest numbers of peoples in the world are using Facebook.

Because through Facebook people feel that they are in contact with the rest of the world, regardless of distances, they can remain updated about the current issues, and other topics of their interest $\frac{1,2}{12}$. Hence Facebook nowadays is regarded as a very useful tool of communication and information. Facebook provides opportunities so that students can share their views, events, celebrations and wishes to their closer ones. Sharing of pictures, videos and other activities is also very common and popular on Facebook ${ }^{3.4}$.

However, the Facebook is advantageous for students because it provides extra and additional knowledge to

${ }^{*}$ Author for correspondence 
them, Students at all levels, especially at higher education level are using Facebook as an account which is helping them to come in contact with different peoples from anywhere in the world. Through the Facebook networking, student community, improving and enhancing their knowledge about the different disciplines of their places, studies, cultures and customs. For Facebook communication students are required to learn English, because English is the international language through which they can chat with their international friends in other countries ${ }^{5,1}$.

Facebook and other Social networking platforms are providing opportunities' to students to become technologically sufficient and efficient. The common and popular trends of using Facebook with students are creating a group for study, learning about their homework, assignments, exams, etc. on the other side, there are some bad effects of social networking sites; include Facebook like students waste lot of precious time in reading Facebook posts or chatting with online friends. Students have to bear the financial burden as they have to pay internet costs. Research study carried out by ${ }^{6}$ stated that users of Facebook especially students, always remain eager to get update information or update their status. So every time, without thinking that Facebook use will take their lot of time, they use it. Students may have studied distraction; they may avoid to do homework and to study before the exams. $\operatorname{In}^{7}$ found that students spent a lot of time on SNS instead of doing class work, studying the course subjects, and doing exams perpetration. Excessive use of Facebook effecting students' performance in examinations badly. Unnecessary use of Facebook causes negative impacts on a student's performance in school examinations. Excessive users get significantly lower (GPA) compared to non-users $\stackrel{8}{\text {. }}$.

Social networking or social media have become integral part of educational systems, the university students are majority user population of social networking sites, and the Facebook is most popular and highly used platform for students. 'It's unlimited access and abundance of all kinds of material/literature is causing positive and negative impacts on university students. One side they have an easy and quick access to updated knowledge and information, of all subjects and disciplines, they have a national and international friends group, collaborative learning opportunities, and exchange new and innovative ideas for sharing. On the other hand, students are exposed to yellow suites, wastage of study time, immoral and bad habits, terrorism, character assassination fake, and fraud and furrieries. The present study aimed at to assess the positive/negative impacts of Facebook ${ }^{\text {}}$.

\section{Research Objectives}

The following research objectives were formulated for the study;

- To examine the influence of Facebook on education of the students.

- To evaluate the utilization of Facebook by the students.

- To recommend the measures for effective use of Facebook in education.

\section{Methodology}

The descriptive survey research method was used to conduct the study. The population of the study comprised of all students enrolled in B.Ed. (Elementary) Program in the year (2018) in the Faculty of Education, University of Sindh and in the Department of Education, University of Karachi. The Table 1 shows the population of the study.

Table 1. Population of the Study

\begin{tabular}{|l|l|l|}
\hline S.No & Name of University & Number of Students \\
\hline 1 & $\begin{array}{l}\text { Faculty of Education, } \\
\text { University of Sindh. }\end{array}$ & 250 \\
\hline 2 & $\begin{array}{l}\text { Department of Education, } \\
\text { University of Karachi. }\end{array}$ & 484 \\
\hline & Total & 734 \\
\hline
\end{tabular}

Source: QEC office of Universities (2018)

(300) students were selected randomly from the population, for data collection from both of the universities. The following shows the sample and population of the study.

The questionnaire was used for data collection. Questionnaire was developed with the help of literature reviewed. Before administration of the questionnaire, it was pilot tested on the (20) students that were excluded from the sample. The reliability of the questionnaire is 0.78 .

\section{Data Analysis and Discussion}

\subsection{Influence of Facebook on Students.} (Research Objective 01)

Table 2 indicates that majority of respondents agreed that Facebook provide many benefits to the students in the field of education, Facebook has become an important and quick source to seek latest knowledge and current information, Facebook is essential for students to enhance 
Table 2. Influence of Facebook on Students

\begin{tabular}{|l|l|l|l|l|l|l|l|}
\hline S\# & Statements & Agreed & UND & DA & Total & $\begin{array}{l}\text { Chi } \\
\chi^{2}\end{array}$ & Inference \\
\hline 1 & $\begin{array}{l}\text { Facebook is advantageous in the } \\
\text { field of education for students }\end{array}$ & $65 \%$ & $12 \%$ & $23 \%$ & 225 & 97.2 & $\begin{array}{l}\text { Significant } \\
\text { (Agreed) }\end{array}$ \\
\hline 2 & $\begin{array}{l}\text { Facebook is affecting negatively } \\
\text { on a study of students. }\end{array}$ & $69 \%$ & $12 \%$ & $19 \%$ & 225 & 107.2 & $\begin{array}{l}\text { Significant } \\
\text { (Agreed) }\end{array}$ \\
\hline 3 & $\begin{array}{l}\text { On Facebook wage and fake } \\
\text { information creates alot of } \\
\text { confusion and ambiguity in the } \\
\text { minds of students. }\end{array}$ & $68 \%$ & $13 \%$ & $19 \%$ & 225 & 81.2 & $\begin{array}{l}\text { Significant } \\
\text { (Agreed) }\end{array}$ \\
\hline 4 & $\begin{array}{l}\text { Facebook has become an } \\
\text { important and quick source } \\
\text { to seek latest knowledge and } \\
\text { current information. }\end{array}$ & $75 \%$ & $8 \%$ & $17 \%$ & 225 & 127.6 & $\begin{array}{l}\text { Significant } \\
\text { (Agreed) }\end{array}$ \\
\hline 5 & $\begin{array}{l}\text { Facebook is essential for students } \\
\text { to get learning and skills }\end{array}$ & $51 \%$ & $14.67 \%$ & $34 \%$ & 225 & 76 & $\begin{array}{l}\text { Significant } \\
\text { (Agreed) }\end{array}$ \\
\hline 6 & $\begin{array}{l}\text { The study group is necessary for } \\
\text { collaborative learning }\end{array}$ & $75 \%$ & $12 \%$ & $13 \%$ & 225 & 132.8 & $\begin{array}{l}\text { Significant } \\
\text { (Agreed) }\end{array}$ \\
\hline
\end{tabular}

Table 3. Utilization of Facebook by the students

\begin{tabular}{|l|l|l|l|l|l|l|}
\hline S\# & Statements & SA & UND & SDA & $\begin{array}{l}\text { Chi } \\
\chi^{2}\end{array}$ & Inference \\
\hline 1 & $\begin{array}{l}\text { Facebook is necessary for students now a } \\
\text { day. }\end{array}$ & $47 \%$ & $9 \%$ & $44 \%$ & 26.8 & $\begin{array}{l}\text { In significant } \\
\text { (Disagreed) }\end{array}$ \\
\hline 2 & $\begin{array}{l}\text { Facebook has become a good hobby for the } \\
\text { students to kill their lazier time. }\end{array}$ & $87 \%$ & $5.33 \%$ & $8 \%$ & 204.8 & $\begin{array}{l}\text { In significant } \\
\text { (Disagreed) }\end{array}$ \\
\hline 3 & $\begin{array}{l}\text { Facebook has a positive impact on you. } \\
4\end{array}$ & $60 \%$ & $8 \%$ & $32 \%$ & 72.8 & $\begin{array}{l}\text { Significant } \\
\text { (Agreed) }\end{array}$ \\
\hline 5 & $\begin{array}{l}\text { The social norms and ethics of the students } \\
\text { are deteriorated by the use of Facebook. } \\
\text { improvem is playing a positive role in the }\end{array}$ & $46.67 \%$ & $13.33 \%$ & $40 \%$ & 26 & $\begin{array}{l}\text { Significant } \\
\text { (Agreed) }\end{array}$ \\
\hline 6 & $\begin{array}{l}\text { Facebook is creating awareness among } \\
\text { students for new trends }\end{array}$ & $77.33 \%$ & $5.33 \%$ & $17.33 \%$ & 165.2 & $\begin{array}{l}\text { Significant } \\
\text { (Agreed) }\end{array}$ \\
\hline 7 & $\begin{array}{l}\text { Facebook is a useful source to link the } \\
\text { people all over the world }\end{array}$ & $85 \%$ & $6.67 \%$ & $8 \%$ & 219.2 & $\begin{array}{l}\text { Significant } \\
\text { (Agreed) }\end{array}$ \\
\hline 8 & $\begin{array}{l}\text { Facebook is playing a vital role in creating } \\
\text { social and political awareness in the } \\
\text { students. }\end{array}$ & $64 \%$ & $13.33 \%$ & $22.67 \%$ & 82.4 & $\begin{array}{l}\text { Significant } \\
\text { (Agreed) }\end{array}$ \\
\hline
\end{tabular}

learning and skills by forming study groups on Facebook. However, on the other hand, it was responded that use of Facebook hasnegative effects for students as well. Its use is spreading vague and fake information which is creating confusion and ambiguity in the minds of students.

The findings were aligned with the study conducted by $^{4}$, he explored the positive and negative impacts of Facebook on students' study habits. The findings of his study showed that excessive use social networking sites including Facebook have negative impact on study habits of students.

\subsection{Utilization of Facebook by the Students. (Research Objective 02)}

Table 3 shows that the majority of students agreed that Facebook has become a good hobby for the students to kill their leisure time, it is useful source to link the people 
around the world and Facebook is generating awareness among students for new trends. About $60 \%$ students viewed that Facebook has positive impacts and it is playing a vital role in creating social and political awareness among the students. Mixed response was found about the statement that Facebook is necessary for students nowadays and the social norms and ethics of the students are deteriorated by the use of Facebook. $\operatorname{In}^{10}$ studied students' learning nature and their engagement related to Facebook. Data were collected regarding students' Facebook usage and activities. Findings of her study revealed that with the use of Facebook in the teaching-learning process, both teachers and students getting good and satisfactory results and they enjoy teaching and learning. Different factors directing the student community to use Facebook like searching new information, entertainment, spending time, socialization, meeting new student friends, surfing, and updating status ${ }^{11}$. In ${ }^{12-14}$ found that use of Facebook is spreading negative effects like anxiety, behavioral and psychological problems, mental health and loss of personal productivity.

\section{Conclusion and Recommendations}

It is concluded that Facebook use by students has become both advantageous and disadvantageous. Some regard Facebook as a fantastic social networking tool because students use it for searching new information, entertainment, killing leisure time, socialization, meeting new friends, surfing, and updating status etc.. It is a quick source to seek latest knowledge and current information, and essential for students to enhance their learning and skills. It is also playing an important role in creating social and political awareness among the students. Through the use of Facebook in teaching-the learning process, both teachers and students are getting maximum benefits. Some regard Facebook as hazardous because excessive use of Facebook creates isolation, anxiety, bad study habits, behavioral and psychological problems, and loss of personal productivity. It also negatively effects on lifestyle, playing and physical activities of students. Social norms and ethics of the students are deteriorated by the use of Facebook because vague and fake information which create confusion and ambiguity in the minds of students. It is also a reality that student community can't help to use Facebook. However, if some limitations should be taken into account, then use of Facebook can be more beneficial for the student community. It should be used purely for educational and communication purposes only. Parents are required to remain aware about the Facebook account of their children. Awareness campaigns are required to aware teachers, parent and students about the proper utilizations of social media in teaching learning process. Government/Bureaue of Curriculum also required developing local software based on text books for different subjects. The use of technology in Teacher Education programs should be enhanced, so that students must know how to use technology for making education fun and interesting.

\section{Reference}

1. Zia A, Paracha SA, Jan M. Usage of Social Networking Website (YouTube) by Teenagers in Lahore, Pakistan. Global Media Journal: Pakistan Edition. 2012; 5(2):1-12.

2. Westlake EJ. Friend me if you Facebook: Generation Y and performative surveillance. The Drama Review. 2008; 52(4):21-40. https://doi.org/10.1162/dram.2008.52.4.21

3. Shabir G. The Impact of Social Media on Youth: A Case Study of Bahawalpur City. Asian Journal of Social Sciences and Humanities. 2014; 3(4):132-51.

4. Gok T. The effects of social networking sites on students' studying and habits. International Journal of Research in Education and Science (IJRES). 2016; 2(1):85-93. https://doi.org/10.21890/ijres.10682

5. Al-Dheleai YM, Zaidatun T. Using Facebook for the Purpose of Students Interaction and its Correlation with Students Academic Performance. TOJET: The Turkish Online Journal of Educational Technology. 2017; 16(4):170-8.

6. The Facebook effect: The real inside story of Mark Zuckerberg and the world's fastest growing company. Available from: https://www.amazon.in/Facebook-EffectZuckerberg-Fastest-Growing-ebook/dp/B008BRF7ZC. Date accessed: 26/06/2012.

7. Wang Q, Chen W, Liang, Y. The effects of social media on college students. MBA Student Scholarship. 2012; 5:1-12.

8. Kirschner PA, Karpinski AC. Facebook and academic performance. Computers in Human Behavior. 2010; 26:1237-45. https://doi.org/10.1016/j.chb.2010.03.024

9. Balcikanli C. Prospective English language teachers' experiences in Facebook: Adoption, use and educational use in Turkish context. International Journal of Education and Development using Information and Communication Technology. 2015; 11(3):82-99.

10. Jenny WANG. What higher educational professionals need to know about today's students: Online social net- 
works. TOJET: The Turkish Online Journal of Educational Technology. 2013; 12(3):180-93.

11. Satici SA, Uysal R. Well-being and problematic Facebook use. Computers in Human Behavior. 2015; 49:185-90. https://doi.org/10.1016/j.chb.2015.03.005

12. Social networking teens more likely to drink, use drugs, study finds. Available from: https://jjie.org/2011/08/24/ teens-on-facebook-more-likely-drink-or-use-drugs-studyfinds/. Date accessed: 24/08/2011.
13. Donlan L. Exploring the views of students on the use of Facebook in university teaching and learning. Journal of Further and Higher Education. 2014; 38(4):572-88. https://doi.org/10.1080/0309877X.2012.726973

14. Li X, Chen W. Facebook or Renren? A comparative study of social networking site use and social capital among Chinese International students in the United States. Computers in Human Behavior. 2014; 35:116-23. https://doi.org/10.1016/j.chb.2014.02.012 